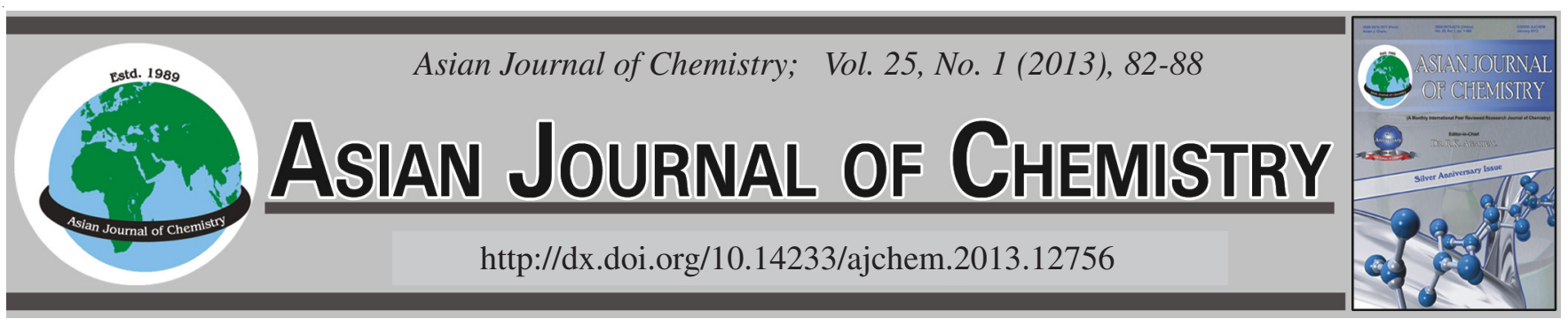

\title{
Thermodynamic and Kinetic Study of Competitive Adsorption Between Sodium Anthraquinone-1-Sulfonate and Xylenol Orange on Expanded Graphite
}

\author{
XIU-YAN PANG ${ }^{*}$ and XING DI
}

College of Chemistry and Environmental Science, Hebei University, Baoding 071002, P.R. China

*Corresponding author: E-mail: pxy833@163.com

\begin{abstract}
In the present study, expanded graphite is prepared through chemical oxidation method. Its adsorption and competitive adsorption thermodynamic and kinetic characteristics in aqueous solution for sodium anthraquinone-1-sulfonate and xylenol orange with difference in molecular weights is studied. The influence of adsorbates concentration, temperature and ionic strength on adsorption and competitive capacity are also examined. In single component system, adsorption isotherm of sodium anthraquinone-1-sulfonate on expanded graphite is type I and type II for xylenol orange. In dual component system, the existence of another component would greatly decrease the adsorbance of expanded graphite for xylenol orange or sodium anthraquinone-1-sulfonate, which might be caused by the competitive adsorption for the same adsorbing site on expanded graphite. The competitive adsorption isotherms are the same as that of the single component system. Adsorption of sodium anthraquinone-1-sulfonate and xylenol orange on expanded graphite is spontaneous and the increase of ionic strength, temperature and pore area of expanded graphite would cause the increase of adsorption capacity. No matter the single component system or the dual component system, the adsorption kinetic models can all be well described with pseudo secondorder model. Adsorption rate increases with the increase of temperature. Physical adsorption is the main action between expanded graphite with these adsorbates.
\end{abstract}

Key Words: Expanded graphite, Sodium anthraquinone-1-sulfonate, Xylenol orange, Competitive adsorption, Adsorption thermodynemics, Adsorption kinetics.

\section{INTRODUCTION}

Most of the industries such as textiles, paper, leather, cosmetic, etc., use dyes or pigments to colour their final products. Such extensive use of colour often produce a mass of coloured wastewaters that require pretreatment for colour prior to disposal into receiving water bodies or treatment works. Most of the commercially used dyes are resistant to biodegradation, photodegradation and oxidizing agent. Adsorption is a kind of effective measure, active carbon ${ }^{1-4}$, modified $\mathrm{Al}_{2} \mathrm{O}_{3}{ }^{5}$, anion exchange resin ${ }^{6}$, active sludge $e^{7,8}$, peat, steel plant slag and fly ash have been reported to be employed for the treatment of dyes ${ }^{9}$.

Expanded graphite (EG) is a new kind of adsorbent with abundant 4 levels pores with the size ranging from nanometer scale to micron scale ${ }^{10}$. It has attracted attentions of scientists and engineers as for its high adsorption capacity to organic materials, such as heavy oil, dyes, aromatic sulfonates, poly(ethylene glycol), etc. ${ }^{11-18}$. Actually, pollutants rarely exist solely in single component, but the adsorption research for them on expanded graphite often carried in single component system. So it is important to study its adsorption capacity in dual component or multicomponent. The study can veritably reveal the characteristics of competitive adsorption on the same site, distribution and adsorbance difference caused by the physical or chemical interaction. The objective of the research is to study dual component competitive adsorption characteristics of sodium anthraquinone-1-sulfonate (SAS) and xylenol orange $(\mathrm{XO})$ on expanded graphite, investigate its adsorption thermodynamic and kinetic characteristics.

\section{EXPERIMENTAL}

Preparation and structure characteristics of expanded graphite adsorbent: With the mass ratio of $1.0: 0.12: 5.0$ of $\mathrm{C}: \mathrm{KMnO}_{4}: \mathrm{H}_{2} \mathrm{SO}_{4}(96 \%)$, the definite amount of graphite carbon, $\mathrm{KMnO}_{4}$ and $\mathrm{H}_{2} \mathrm{SO}_{4}$ (diluted to a mass concentration of $75 \%$ with de-ionized water before mixed with graphite) are mixed under room temperature. Reaction lasts $0.5 \mathrm{~h}$ under stirring, then the products are washed with de-ionized water until $\mathrm{pH}$ reached to 6-7. After filtration and dryness under 80 ${ }^{\circ} \mathrm{C}$, the solid scale like grains are heated at $900{ }^{\circ} \mathrm{C}$ for $c a .10 \mathrm{~s}$ and then expanded graphite can be gained. Its expansion volume $(\mathrm{EV})$ is detected according to GB10698-89 ${ }^{19}$. Expanded graphites with different expansion volume are prepared using 
raw material graphite with different size of $0.3,0.18$ and 0.15 $\mathrm{mm}$ (Table-1). The specific surface, pore size distribution and pore cubage are detected with micromeritics instrument corporation tri star II $3020 \mathrm{~V} 1.02$ and pore structure parameters are calculated with BET method as listed in Table-1. In all the adsorption and competitive adsorption experiments, expanded graphite with an expansion volume of $400 \mathrm{~mL} \mathrm{~g}^{-1}$ is used as adsorbent except for the special illustration.

\begin{tabular}{ccccc}
\multicolumn{6}{c}{ TABLE-1 } \\
\multicolumn{6}{c}{ STRUCTURAL PARAMETER OF EXPANDED GRAPHITES (EGs) } \\
\hline $\begin{array}{c}\text { Materials } \\
\text { size } \\
(\mathrm{mm})\end{array}$ & $\begin{array}{c}\text { EV of } \\
\text { EGs } \\
\left(\mathrm{mL} \mathrm{g}^{-1}\right)\end{array}$ & $\begin{array}{c}\text { Total } \\
\text { intrusion vol- } \\
\text { ume }\left(\mathrm{cm}^{3} \mathrm{~g}^{-1}\right)\end{array}$ & $\begin{array}{c}\text { Total pore } \\
\text { area } \\
\left(\mathrm{m}^{2} \mathrm{~g}^{-1}\right)\end{array}$ & $\begin{array}{c}\text { Average pore } \\
\text { diameter } \\
\text { 4V/A }(\mathrm{nm})\end{array}$ \\
\hline 0.3 & 400 & 0.1009 & 34.35 & 11.61 \\
0.18 & 150 & 0.0698 & 23.84 & 11.61 \\
0.15 & 35 & 0.06263 & 21.30 & 11.59 \\
\hline
\end{tabular}

Adsorbate characteristics: Sodium anthraquinone-1sulfonate and xylenol orange with obvious difference in molecular weight are used as adsorbate compounds. Chemical structure and molecular weight are showed in Table-2. Simulated wastewaters of sodium anthraquinone-1-sulfonate and xylenol orange in single component and in dual component are prepared by dissolving these adsorbates in de-ionized water at various concentrations. Before quantitative analysis, absorption spectrum of sodium anthraquinone-1-sulfonate and xylenol orange is detected (Fig. 1) and quantitative equations are given in Table-3.

Static adsorption in single component system and dual component system: $0.20 \mathrm{~g}$ of expanded graphite is mixed in different conical glass flasks with $100 \mathrm{~mL}$ solution at the desired adsorbates concentration and ionic strength. Ionic strength is adjusted with $\mathrm{NaCl}$ or $\mathrm{Na}_{2} \mathrm{SO}_{4}$ solution. Mass of expanded graphite to volume of solution is standardized as

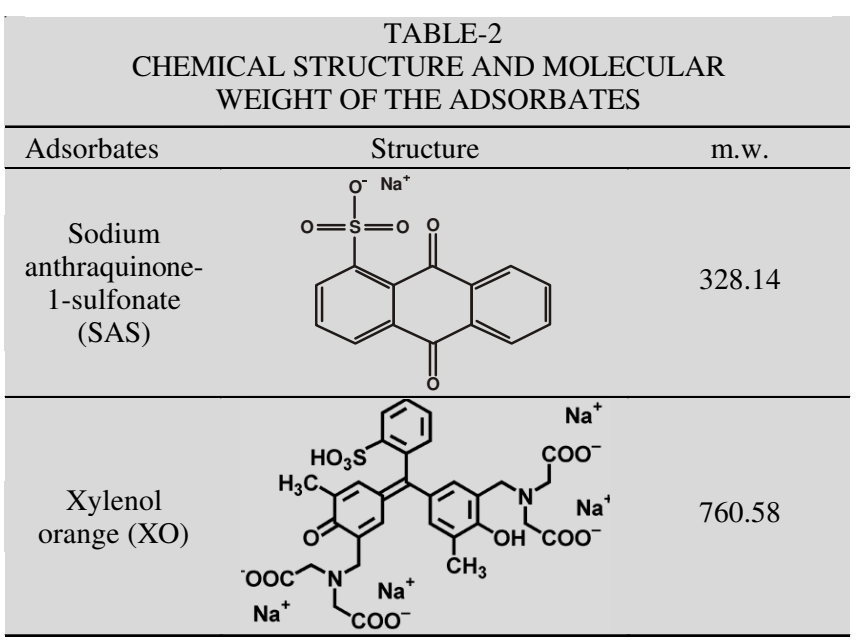

\begin{tabular}{|c|c|c|c|}
\hline \multicolumn{4}{|c|}{$\begin{array}{c}\text { TABLE-3 } \\
\text { QUANTITIVE EQUATION OF SAS AND XO }{ }^{\mathrm{a}}\end{array}$} \\
\hline & $\lambda(\mathrm{nm})$ & Equation & $\mathrm{r}$ \\
\hline \multirow{2}{*}{ XO } & 436 & $Y=0.01922+0.01501 x$ & 0.9991 \\
\hline & 330 & $Y=0.00375+0.00231 x$ & 0.9990 \\
\hline SAS & 330 & $Y=0.01605 x-0.00262$ & 0.9990 \\
\hline
\end{tabular}

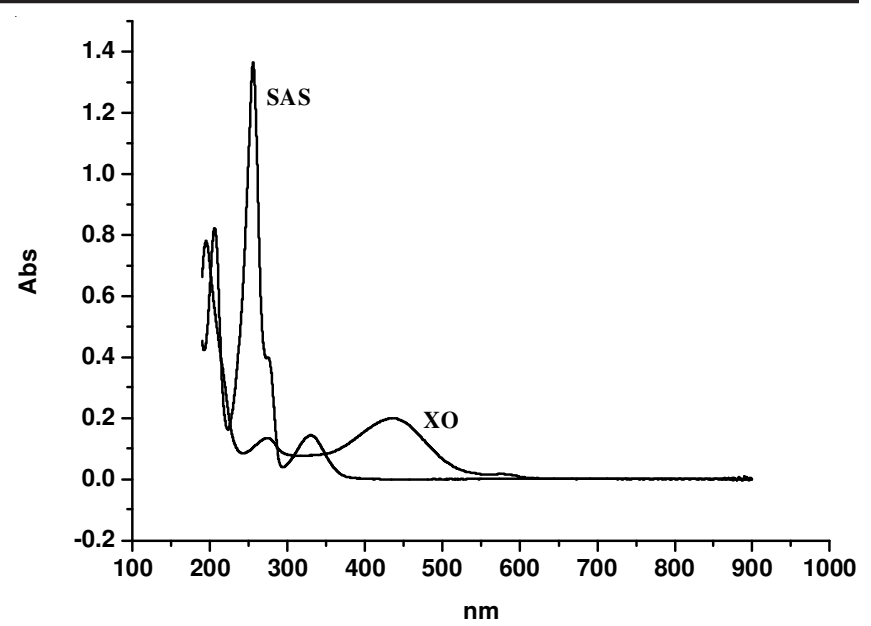

Fig. 1. Absorption spectrum of sodium anthraquinone-1-sulfonate (SAS) and xylenol orange (XO)

$\mathrm{M} / \mathrm{V}=0.200 / 0.1=2 \mathrm{~g} \mathrm{~L}^{-1}$, the equilibrium time for xylenol orange is about $24 \mathrm{~h}$ and $6 \mathrm{~h}$ for sodium anthraquinone-1sulfonate and it's not affected by adsorbate concentration. Absorbance and concentration changes of the adsorbates are recorded with spectrophotometer and calculated according to equation listed in Table-3 and adsorbance is calculated according to equation (1).

$$
\mathrm{q}=\mathrm{V}\left(\mathrm{C}_{0}-\mathrm{C}\right) / \mathrm{M}
$$

where, q: Adsorbance of adsorbate on expanded graphite, $\mathrm{mg}$ $\mathrm{g}^{-1} ; \mathrm{C}_{0}$ : Initial concentration of adsorbate in solution, $\mathrm{mg} \mathrm{L}^{-1}$; $\mathrm{C}$ : Concentration of adsorbate in solution, $\mathrm{mg} \mathrm{L}^{-1}$; V: Volume of solution, L; M: Mass of expanded graphite, g. When adsorption reaches equilibrium, $\mathrm{C}$ and $\mathrm{q}$ can be written as $\mathrm{C}_{\mathrm{e}}$ and $\mathrm{q}_{\mathrm{e}}$, respectively.

Adsorption capacity of expanded graphite under the influence of expanded graphite' expansion volume, ionic strength and temperature: Expanded graphites with different expansion volume are used to detect the influence of adsorbent structure on adsorption capacity. $\mathrm{NaCl}$ and $\mathrm{Na}_{2} \mathrm{SO}_{4}$ are used to adjust ionic strength of solution. 15, 25 and $35^{\circ} \mathrm{C}$ are controlled in kinetic studies. Adsorbance and equilibrium adsorbance are calculated according to equation (1).

\section{RESULTS AND DISCUSSION}

Adsorption and competitive adsorption isotherm: Static adsorption and competitive adsorption isotherm of sodium anthraquinone-1-sulfonate and xylenol orange are measured under $15{ }^{\circ} \mathrm{C}$. Results showed in Fig. 2. In single component system, adsorption isotherm of sodium anthraquinone-1-sulfonate on expanded graphite is type I and type II for xylenol orange; In the dual component system, the existence of another component would greatly decrease the adsorbance of expanded graphite for xylenol orange or sodium anthraquinone-1-sulfonate, which might be caused by the competitive adsorption for the same adsorbing site on expanded graphite, but the competitive adsorption isotherms are the same as that of the single component.

To describe the effect of adsorbate concentration and possible conformation in the interfacial region, Langmuir and Freundlich isotherm equations (2) and (3) are used to treat the isotherm data. As showed in Table-4, Langmuir equation has 

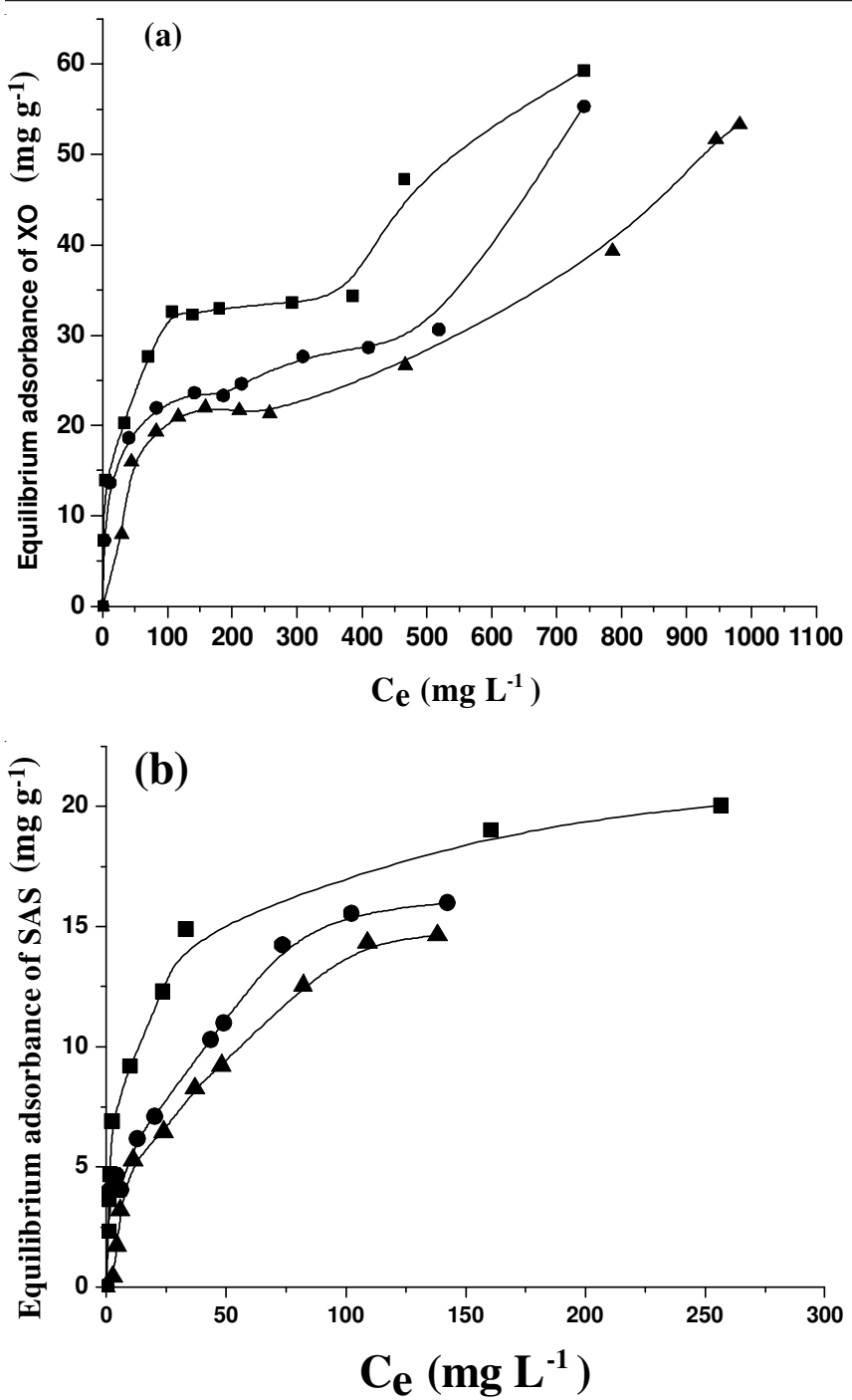

Fig. 2. Adsorption isotherm and competitive adsorption isotherm; (a) xylenol orange (b)sodium anthraquinone-1-sulfonate; (a) Concentration of sodium anthraquinone-1-sulfonate is (匹) $0 \mathrm{mg} \mathrm{L}$

${ }^{1}$; (•) $50 \mathrm{mg} \mathrm{L}^{-1}$; (४) $300 \mathrm{mg} \mathrm{L}^{-1}$, (b) Concentration of xylenol orange

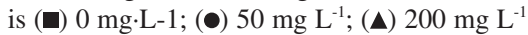

\begin{tabular}{|c|c|c|c|c|c|c|c|}
\hline \multicolumn{8}{|c|}{$\begin{array}{c}\text { TABLE-4 } \\
\text { LANGMUIR AND FREUNDLICH ISOTHERM } \\
\text { CONSTANTS AT } 15^{\circ} \mathrm{C}\end{array}$} \\
\hline & \multirow{2}{*}{$\begin{array}{l}\text { Adsor- } \\
\text { bates }\end{array}$} & \multicolumn{3}{|c|}{ Langmuir } & \multicolumn{3}{|c|}{ Freundlich } \\
\hline & & $\begin{array}{c}\mathrm{q}_{\mathrm{o}}(\mathrm{mg} \\
\left.\mathrm{g}^{-1}\right)\end{array}$ & A & $\mathrm{r}$ & $\mathrm{K}_{\mathrm{F}}$ & $1 / n$ & $\mathrm{r}$ \\
\hline \multirow{2}{*}{$\begin{array}{l}\text { Adso- } \\
\text { rption }\end{array}$} & XO & 39.55 & 0.0393 & 0.996 & 8.0441 & 0.2784 & 0.976 \\
\hline & SAS & 16.90 & 0.0722 & 0.993 & 3.7690 & 0.3340 & 0.944 \\
\hline \multirow{4}{*}{$\begin{array}{l}\text { Comp- } \\
\text { etitive } \\
\text { adso- } \\
\text { rption }\end{array}$} & $\begin{array}{l}\text { SAS 50 } \\
\left(\mathrm{mg} \mathrm{L}^{-1}\right) \\
\end{array}$ & 26.16 & 0.0201 & 0.985 & 5.9917 & 0.2814 & 0.953 \\
\hline & $\begin{array}{c}\text { ASA } 300 \\
\left(\mathrm{mg} \mathrm{L}^{-1}\right)\end{array}$ & 21.07 & 0.0171 & 0.977 & 2.4572 & 0.4253 & 0.941 \\
\hline & $\begin{array}{c}\mathrm{XO} 50 \\
\left(\mathrm{mg} \mathrm{L}^{-1}\right) \\
\end{array}$ & 15.09 & 0.0673 & 0.999 & 3.5140 & 0.2715 & 0.972 \\
\hline & $\begin{array}{l}\text { XO } 200 \\
\left(\mathrm{mg} \mathrm{L}^{-1}\right)\end{array}$ & 12.53 & 0.0534 & 0.998 & 1.8200 & 0.287 & 0.965 \\
\hline
\end{tabular}

$\mathrm{SAS}=$ Sodium anthraquinone-1-sulfonate $\mathrm{XO}=$ Xylenol orange

better linear relationship than Freundlich equation for single adsorption and competitive adsorption, which indicates that Langmuir model can preferably simulate the single layer adsorption of sodium anthraquinone-1-sulfonate and xylenol orange on expanded graphite. Existence of the second component causes the decrease of adsorbate' saturation absorbance compared with the single component system, which reveals that there are competitive adsorption between sodium anthraquinone-1-sulfonate and xylenol orange on the same aperture sites.

$$
\text { Langmuir equation: } \mathrm{q}=\mathrm{q}_{0} \cdot \mathrm{C} /(\mathrm{A}+\mathrm{C})
$$

Freundlich equation: $\ln \mathrm{q}_{\mathrm{e}}=\ln \mathrm{K}_{\mathrm{F}}+(1 / \mathrm{n}) \ln \mathrm{Ce}$

where, $\mathrm{K}_{\mathrm{F}}=$ Freundlich equilibrium constant; $\mathrm{A}=$ equilibrium concentration of adsorbate corresponding to half saturation adsorbance; $\mathrm{q}_{0}=$ saturation absorbance; $1 / \mathrm{n}=$ Freundlich adsorption strength.

Adsorption free energy changes $\left(\Delta \mathrm{G}^{\mathrm{o}}\right)$ are calculated according to equation (4). Negative $\left(\Delta \mathrm{G}^{\circ}\right)$ indicate that adsorption and competivition adsorption of these adsorbates on expanded graphite are all spontaneous (Table-5).

$$
\Delta \mathrm{G}^{\mathrm{o}}=-\mathrm{RT} \ln (\mathrm{b}),(\mathrm{b}=1 / \mathrm{A})
$$

where, $\mathrm{b}=$ Langmuir equation constant, $\mathrm{mL} \mathrm{mg}^{-1} ; \Delta \mathrm{G}^{\mathrm{o}}=$ Free

\begin{tabular}{|c|c|c|c|c|c|c|}
\hline \multicolumn{7}{|c|}{$\begin{array}{c}\text { TABLE-5 } \\
\text { GIBBS ENERGY OF ADSORPTION AND } \\
\text { COMPETITIVE ADSORPTION }\end{array}$} \\
\hline \multirow[t]{2}{*}{$\Delta \mathrm{G}^{\circ}$} & \multicolumn{2}{|c|}{ Adsorption } & \multicolumn{4}{|c|}{ Competitive adsorption } \\
\hline & $\mathrm{XO}$ & SAS & $\begin{array}{c}\mathrm{SAS} \\
50 \\
\left(\mathrm{mg} \mathrm{L}^{-1}\right)\end{array}$ & $\begin{array}{c}\text { SAS } \\
300 \\
\left(\mathrm{mg} \mathrm{L}^{-1}\right)\end{array}$ & $\begin{array}{c}\mathrm{XO} \\
50 \\
\left(\mathrm{mg} \mathrm{L}^{-1}\right)\end{array}$ & $\begin{array}{c}\mathrm{XO} \\
200 \\
\left(\mathrm{mg} \mathrm{L}^{-1}\right)\end{array}$ \\
\hline $\begin{array}{c}\mathrm{kJ} \\
\mathrm{mol}^{-1}\end{array}$ & -8.019 & -10.56 & -9.606 & -10.08 & -3.382 & -3.458 \\
\hline
\end{tabular}
energy change in the adsorption.

Influence of different kinds of expanded graphite on adsorption and competitive adsorption capacity: Adsorption and competitive adsorption studies are carried out using different expanded graphites (Table-1) as adsorbent. As showed in Figs. 3 and 4, increase of expansion volume of these adsorbents enhance the increase of adsorbance in single component system and dual component system. It has no influence on adsorption isotherm, but the equilibrium concentrations corresponding to the saturated adsorbance increase with the decrease of expanded graphite' expansion volume.

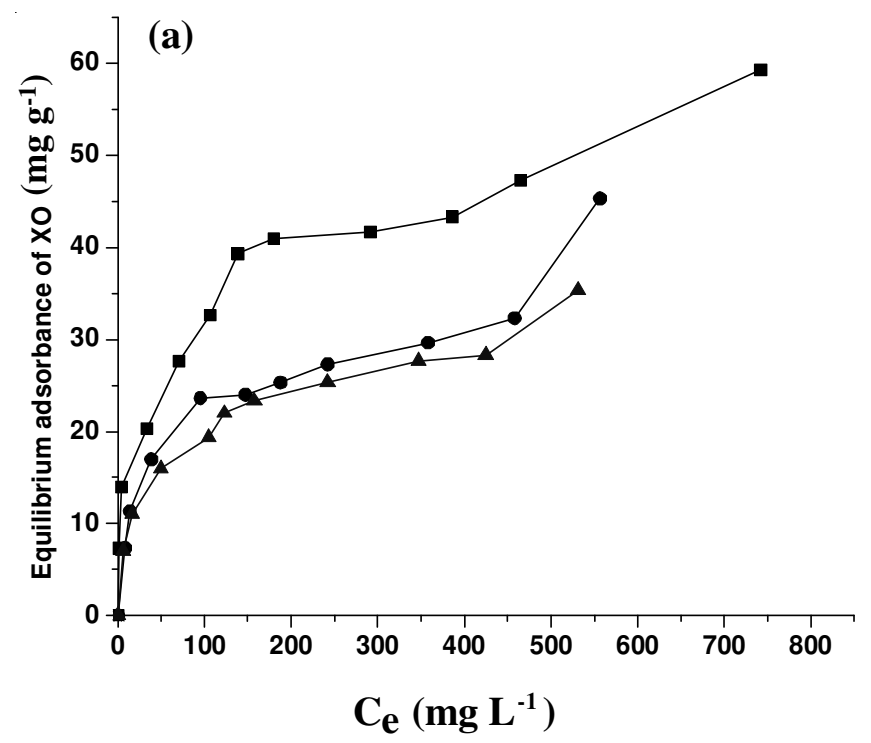




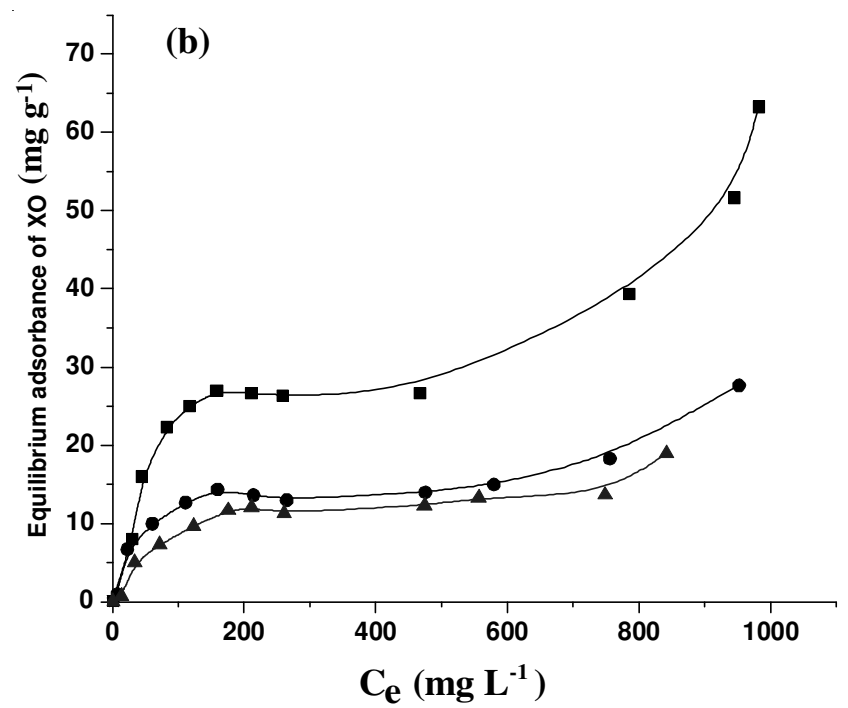

Fig. 3. Influence of adsorbent' expansion volume on adsorption capacity of expanded graphite for xylenol orange concentration of sodium anthraquinone-1-sulfonate is (a) $0 \mathrm{mg} \mathrm{L}^{-1}$ (b) $300 \mathrm{mg} \mathrm{L}^{-1}$; expansion volume of expanded graphite is $(\boldsymbol{\square}) 400 \mathrm{~mL} \mathrm{~g}^{-1},(\bullet) 150 \mathrm{~mL} \mathrm{~g}^{-1},(\boldsymbol{\Delta})$ $35 \mathrm{~mL} \mathrm{~g}^{-1}$
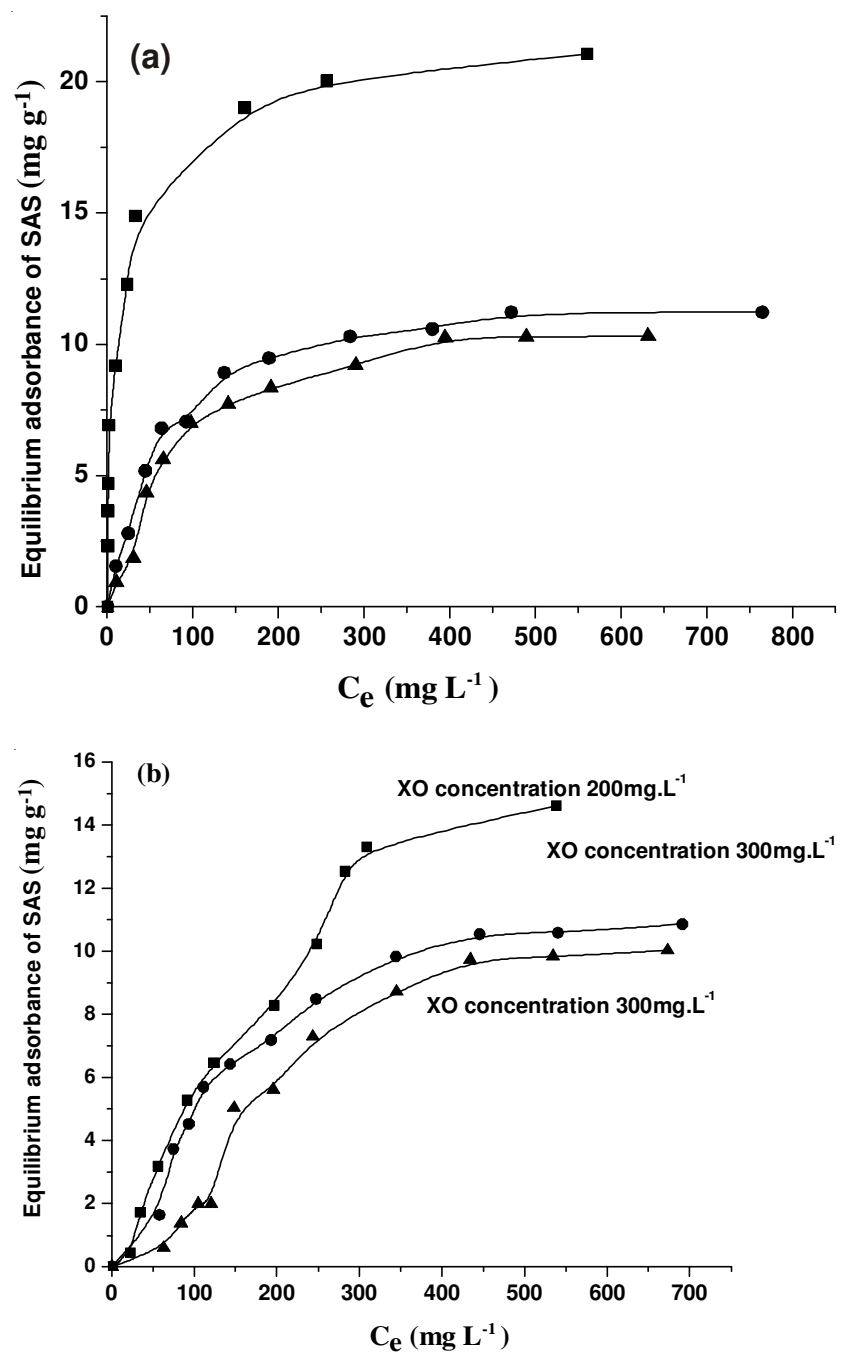

Fig. 4. Influence of adsorbent' expansion volume on adsorption capacity of expanded graphite for sodium anthraquinone-1-sulfonate; Concentration of xylenol orange is (a) $0 \mathrm{mg} \mathrm{L}^{-1}$, (b) $200 \mathrm{mg} \mathrm{L}^{-1}$ and $300 \mathrm{mg} \mathrm{L}^{-1}$; expansion volume of expanded graphite is $(\mathbf{\square}) 400 \mathrm{~mL}$ $\mathrm{g}^{-1},(\bullet) 150 \mathrm{~mL} \mathrm{~g}^{-1},(\mathbf{\Delta}) 35 \mathrm{~mL} \mathrm{~g}^{-1}$
Influence of ionic strength on adsorption and competitive adsorption capacity: Sodium chloride and sodium sulfate are used to adjust ionic strength in the range of 0 to 0.6 mol L $\mathrm{L}^{-1}$ with the concentration of xylenol orange, sodium anthraquinone-1-sulfonate keeping as $200 \mathrm{mg} \mathrm{L}^{-1}$. Figs. 5 and 6 indicate that the presence of ions can improve the adsorption capacity of expanded graphite for these adsorbates and it may be caused by increase of hydrophobic attraction of adsorbates due to the salting-out effect.

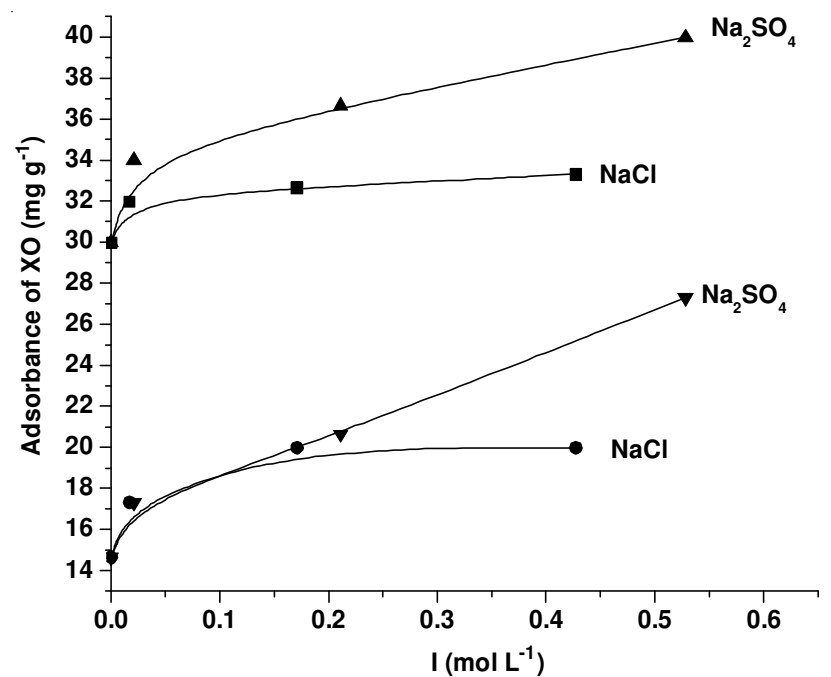

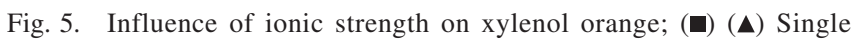
adsorption

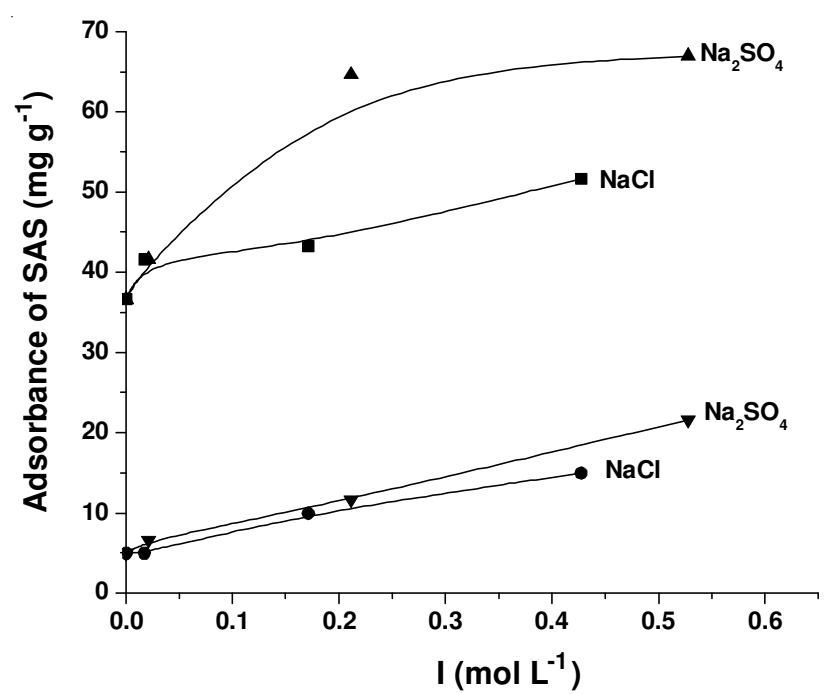

Fig. 6. Influence of ionic strength on sodium anthraquinone-1-sulfonate; $(\bullet)(\nabla)$ Competitive adsorption

Investigation of kinetics parameter of adsorption and competitive adsorption

Influence of adsorbate concentration and temperature on adsorption kinetics: Adsorbance of the adsorbate on expanded graphite is a function of time and adsorbate concentration. As showed in Figs. 7 and 8, in the early stage of the adsorption, adsorbance increased with time, equilibrium time for xylenol orange is $c a$. $24 \mathrm{~h}$ and $6 \mathrm{~h}$ for sodium anthraquinone-1-sulfonate. Equilibrium adsorbance has a little increase with the increase of temperature no matter for single adsorption or competitive adsorption. The results might be caused by the decrease of adsorbates dissolubility in water with the increase of temperature. 

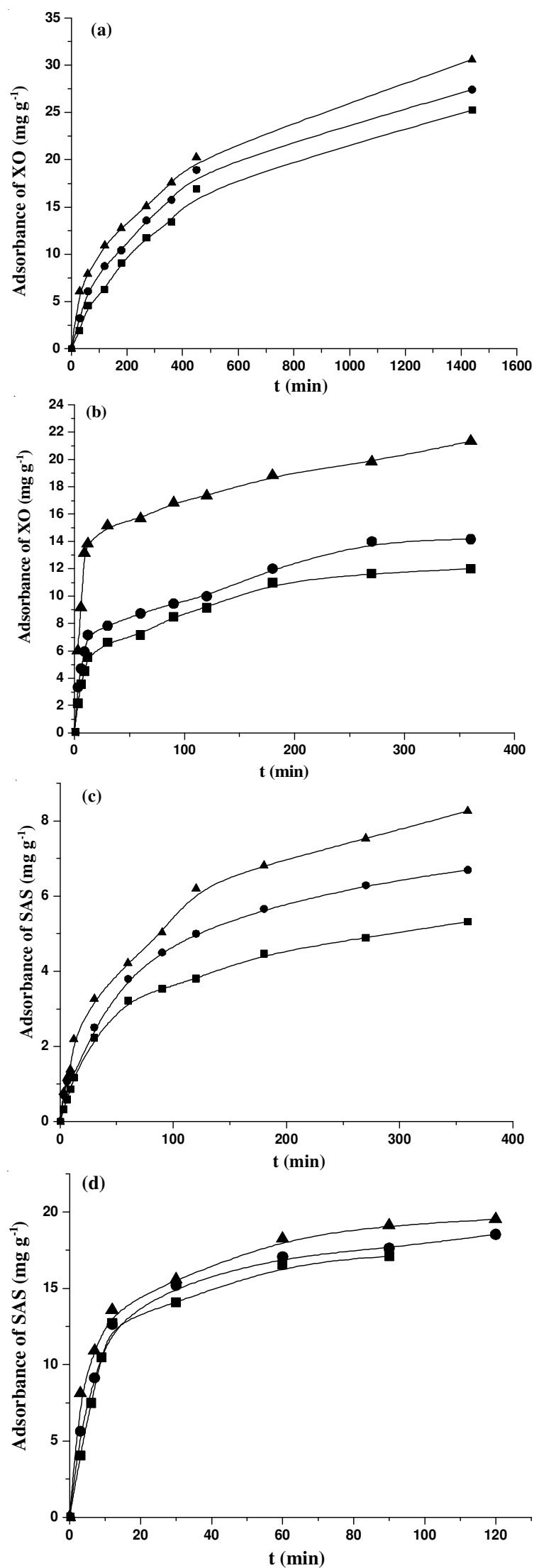

Fig. 7. Influence of temperature on adsorption time in single adsorption and competitive adsorption with adsorbates' initinal concentration of $100 \mathrm{mg} \mathrm{L}^{-1}$; (a) Single adsorption of xylenol orange (b) Competitive adsorption of $100 \mathrm{mg} \mathrm{L}^{-1}$ ASA for xylenol orange (c) Single adsorption of sodium anthraquinone-1-sulfonate (d) Competitive adsorption of $100 \mathrm{mg} \mathrm{L}^{-1}$ xylenol orange for sodium anthraquinone-1-sulfonate $(\boldsymbol{\square}) 15^{\circ} \mathrm{C},(\bullet) 25^{\circ} \mathrm{C},(\boldsymbol{\Lambda}) 35^{\circ} \mathrm{C}$
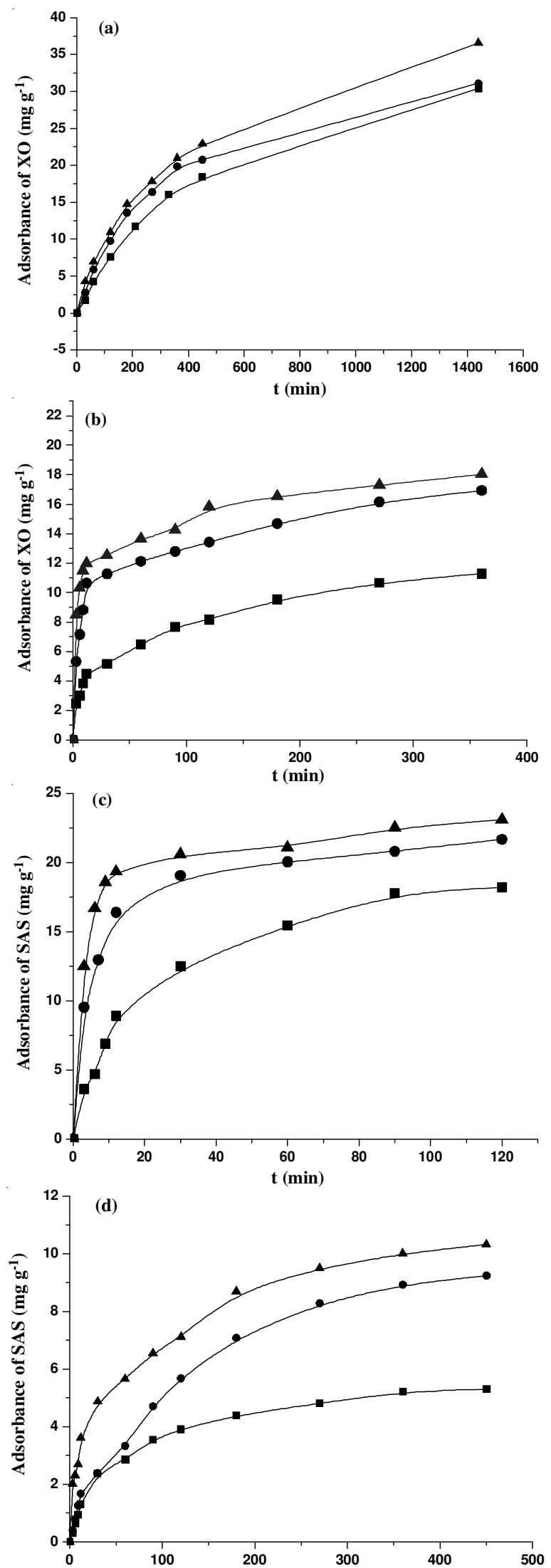

Fig. 8. Influence of temperature on adsorbance in single adsorption and competitive adsorption with adsorbates' initinal concentration of $200 \mathrm{mg} \mathrm{L}^{-1}$; (a) Single adsorption of xylenol orange (b) Competitive adsorption of $200 \mathrm{mg} \mathrm{L}^{-1}$ ASA for xylenol orange; (c) Single adsorption of sodium anthraquinone-1-sulfonate (d) Competitive adsorption of $200 \mathrm{mg} \mathrm{L}^{-1}$ xylenol orange for sodium anthraquinone1-sulfonate; (•) $15{ }^{\circ} \mathrm{C},(\bullet) 25^{\circ} \mathrm{C},(\boldsymbol{\Delta}) 35^{\circ} \mathrm{C}$ 
TABLE-6

COMPARISON OF EXPERIMENTAL DATA WITH ADSORPTION KINETIC MODELS OF XYLENOL ORANGE IN SINGLE ADSORPTION

\begin{tabular}{ccc|ccc|ccc}
\hline \multirow{2}{*}{$\begin{array}{c}\mathrm{C}_{0} \\
\left(\mathrm{mg} \mathrm{L}^{-1}\right)\end{array}$} & $\begin{array}{c}\mathrm{T} \\
\left({ }^{\circ} \mathrm{C}\right)\end{array}$ & $\begin{array}{c}\mathrm{q}_{\mathrm{e}, \text { exp }} \\
\left(\mathrm{mg} \mathrm{g}^{-1}\right)\end{array}$ & \multicolumn{3}{|c|}{ First-order } & \multicolumn{3}{c}{ Second-order } \\
\cline { 4 - 9 } & $\mathrm{q}_{\mathrm{e}, \mathrm{cal}}\left(\mathrm{mg} \mathrm{g}^{-1}\right)$ & $\mathrm{k}\left(\mathrm{min}^{-1}\right)$ & $\mathrm{r}$ & $\mathrm{q}_{\text {e,cal }}\left(\mathrm{mg} \mathrm{g}^{-1}\right)$ & $\mathrm{k} / 10^{-5}\left[\mathrm{~g}(\mathrm{mg} \mathrm{min})^{-1}\right]$ & $\mathrm{r}$ \\
\hline \multirow{3}{*}{100} & 15 & 25.24 & $21.88 \pm 1.049$ & $0.290 \pm 0.048$ & -0.985 & $24.77 \pm 0.00103$ & $6.91 \pm 0.00103$ & 0.996 \\
& 25 & 27.40 & $22.95 \pm 1.04$ & $0.120 \pm 0.010$ & -0.977 & $26.38 \pm 0.0014$ & $8.7 \pm 0.0014$ & 0.993 \\
& 35 & 30.57 & $30.89 \pm 1.042$ & $0.123 \pm 0.01$ & -0.980 & $30.33 \pm 0.0020$ & $10 \pm 0.00203$ & 0.984 \\
\hline \multirow{3}{*}{200} & 15 & 30.40 & $28.31 \pm 1.04$ & $0.118 \pm 0.010$ & -0.980 & $31.39 \pm 0.00036$ & $4.5 \pm 0.000361$ & 0.999 \\
& 25 & 31.07 & $28.77 \pm 1.0484$ & $0.118 \pm 0.0119$ & -0.971 & $32.69 \pm 0.00039$ & $6.0 \pm 0.000392$ & 0.999 \\
& 35 & 36.56 & $35.74 \pm 1.0421$ & $0.138 \pm 0.0104$ & -0.984 & $35.02 \pm 0.0009$ & $7.2 \pm 0.000991$ & 0.999 \\
\hline
\end{tabular}

TABLE-7

COMPARISON OF EXPERIMENTAL DATA WITH ADSORPTION KINETIC MODELS OF SODIUM ANTHRAQUINONE-1-SULFONATE IN SINGLE ADSORPTION

\begin{tabular}{ccc|ccc|ccc}
\hline \multirow{2}{*}{$\begin{array}{c}\mathrm{C}_{0} \\
\left(\mathrm{mg} \mathrm{L}^{-1}\right)\end{array}$} & $\begin{array}{c}\mathrm{T} \\
\left({ }^{\circ} \mathrm{C}\right)\end{array}$ & $\begin{array}{c}\mathrm{q}_{\mathrm{e}, \text { xp }} \\
\left(\mathrm{mg} \mathrm{g}^{-1}\right)\end{array}$ & \multicolumn{3}{c|}{ First-order } & \multicolumn{3}{c}{ Second-order } \\
\cline { 4 - 9 } & 15 & 21.53 & $12.91 \pm 1.13$ & $0.017 \pm 0.0021$ & -0.958 & $20.89 \pm 0.0018$ & $5.6 \pm 0.0018$ & $\mathrm{r}$ \\
\hline \multirow{3}{*}{100} & 25 & 22.08 & $13.47 \pm 1.11$ & $0.0092 \pm 0.0026$ & -0.932 & $20.90 \pm 0.001$ & $7.1 \pm 0.001$ & 0.995 \\
& 35 & 23.93 & $11.01 \pm 1.14$ & $0.013 \pm 0.0023$ & -0.920 & $21.00 \pm 0.0004$ & $8.8 \pm 0.00041$ & 1 \\
\hline \multirow{3}{*}{200} & 15 & 19.9 & $15.20 \pm 1.07$ & $0.022 \pm 0.012$ & -0.991 & $21.05 \pm 0.0011$ & $2.5 \pm 0.0011$ & 1 \\
& 25 & 23.55 & $9.22 \pm 1.28$ & $0.017 \pm 0.004$ & -0.889 & $22.80 \pm 0.0005$ & $9.8 \pm 0.00048$ & 1 \\
& 35 & 24.49 & $7.798 \pm 1.15$ & $0.014 \pm 0.0024$ & -0.918 & $23.15 \pm 0.0008$ & $17 \pm 0.00083$ & 0.999 \\
\hline
\end{tabular}

TABLE-8

COMPARISON OF EXPERIMENTAL DATA WITH COMPETITIVE ADSORPTION KINETIC MODELS OF XYLENOL ORANGE ${ }^{\mathrm{b}}$

\begin{tabular}{ccc|ccc|ccc}
\hline \multirow{2}{*}{$\begin{array}{c}\mathrm{C}_{0} \\
\left(\mathrm{mg} \mathrm{L}^{-1}\right)\end{array}$} & $\begin{array}{c}\mathrm{T} \\
\left({ }^{\circ} \mathrm{C}\right)\end{array}$ & $\begin{array}{c}\mathrm{q}_{\mathrm{e}, \text { exp }} \\
\left(\mathrm{mg} \mathrm{g}^{-1}\right)\end{array}$ & \multicolumn{3}{|c|}{ First-order } & \multicolumn{3}{c}{ Second-order } \\
\cline { 4 - 9 } 1 & $\mathrm{q}_{\mathrm{e}, \text { cal }}\left(\mathrm{mg} \mathrm{g}^{-1}\right)$ & $\mathrm{k} / 10^{-3}\left(\mathrm{~min}^{-1}\right)$ & $\mathrm{r}$ & $\mathrm{q}_{\mathrm{e}, \text { cal }}\left(\mathrm{mg} \mathrm{g}^{-1}\right)$ & $\mathrm{k} / 10^{-3}\left[\mathrm{~g}(\mathrm{mg} \mathrm{min})^{-1}\right]$ & $\mathrm{r}$ \\
\hline \multirow{2}{*}{100} & 15 & 13.82 & $9.23 \pm 1.06$ & $2.9 \pm 0.00301$ & -0.956 & $12.72 \pm 0.0034$ & $2.2 \pm 0.034$ & 0.993 \\
& 25 & 14.43 & $11.73 \pm 1.05$ & $4.5 \pm 0.00027$ & -0.982 & $14.61 \pm 0.0031$ & $2.4 \pm 0.003$ & 0.992 \\
& 35 & 23.82 & $13.14 \pm 1.18$ & $4.5 \pm 0.0054$ & -0.940 & $21.36 \pm 0.0020$ & $2.9 \pm 0.002$ & 0.992 \\
200 & 15 & 12.32 & $9.28 \pm 1.06$ & $2.18 \pm 0.00030$ & -0.918 & $11.36 \pm 0.005$ & $1.7 \pm 0.005$ & 0.984 \\
& 25 & 20.65 & $10.32 \pm 1.06$ & $3.1 \pm 0.00028$ & -0.960 & $17.12 \pm 0.0031$ & $2.6 \pm 0.0032$ & 0.985 \\
& 35 & 24.15 & $17.21 \pm 1.08$ & $3.3 \pm 0.00040$ & -0.934 & $20.83 \pm 0.0018$ & $3.7 \pm 0.0018$ & 0.995 \\
\hline
\end{tabular}

${ }^{\mathrm{b}}$ Concentrations of competitive component of SAS are $100 \mathrm{mg} \mathrm{L}^{-1}$ and $200 \mathrm{mg} \mathrm{L}^{-1}$

TABLE-9

COMPARISON OF EXPERIMENTAL DATA WITH COMPETITIVE ADSORPTION KINETIC MODELS OF XYLENOL ORANGE

\begin{tabular}{|c|c|c|c|c|c|c|c|c|}
\hline \multirow{2}{*}{$\begin{array}{c}\mathrm{C}_{0} \\
\left(\mathrm{mg} \mathrm{L}^{-1}\right)\end{array}$} & \multirow{2}{*}{$\begin{array}{c}\mathrm{T} \\
\left({ }^{\circ} \mathrm{C}\right)\end{array}$} & \multirow{2}{*}{$\begin{array}{c}\mathrm{q}_{\mathrm{e}, \mathrm{exp}} \\
\left(\mathrm{mg} \mathrm{g}^{-1}\right)\end{array}$} & \multicolumn{3}{|c|}{ First-order } & \multicolumn{3}{|c|}{ Second-order } \\
\hline & & & $\mathrm{q}_{\mathrm{e}, \text { cal }}\left(\mathrm{mg} \mathrm{g}^{-1}\right)$ & $\mathrm{k} / 10^{-3}\left(\min ^{-1}\right)$ & $\mathrm{r}$ & $\mathrm{q}_{\mathrm{e}, \mathrm{cal}}\left(\mathrm{mg} \mathrm{g}^{-1}\right)$ & $\mathrm{k} / 10^{-3}\left[\mathrm{~g}(\mathrm{mg} \mathrm{min})^{-1}\right]$ & $\mathrm{r}$ \\
\hline \multirow{3}{*}{100} & 15 & 6.47 & $4.71 \pm 1.15$ & $4.3 \pm 0.00072$ & -0.883 & $6.01 \pm 0.0034$ & $3.6 \pm 0.0034$ & 0.993 \\
\hline & 25 & 7.83 & $5.06 \pm 1.13$ & $3.8 \pm 0.0006$ & -0.892 & $7.028 \pm 0.0013$ & $7.8 \pm 0.0013$ & 1.0 \\
\hline & 35 & 10.39 & $5.9 \pm 1.05$ & $3.7 \pm 0.00026$ & -0.975 & $11.250 \pm 0.0066$ & $8.6 \pm 0.0066$ & 0.992 \\
\hline \multirow{3}{*}{200} & 15 & 8.54 & $6.96 \pm 1.09$ & $4.5 \pm 0.0004$ & -0.974 & $9.95 \pm 0.00028$ & $3.1 \pm 0.0028$ & 0.956 \\
\hline & 25 & 10.21 & $8.51 \pm 1.06$ & $4.8 \pm 0.0003$ & -0.979 & $10.23 \pm 0.0043$ & $4.3 \pm 0,0042$ & 0.995 \\
\hline & 35 & 12.10 & $11.88 \pm 1.05$ & $4.9 \pm 0.00026$ & -0.986 & $12.96 \pm 0.0081$ & $5.8 \pm 0.0081$ & 0.998 \\
\hline
\end{tabular}

${ }^{c}$ The concentrations of competitive component of xylenol orange are $100 \mathrm{mg} \mathrm{L}^{-1}$ and $200 \mathrm{mg} \mathrm{L}^{-1}$

Adsorption and competitive adsorption kinetic models: The dynamics data of adsorption and competitive adsorption is characterized by pseudo first-order model (eqn. 5) and pseudo Second-order model (eqn. 6) 20,21 $^{2}$

First-order model: $\ln \left(\mathrm{q}_{\mathrm{e}}-\mathrm{q}\right)=\ln \mathrm{q}_{\mathrm{e}}-\mathrm{k}_{\mathrm{t}}$

Second-order model: $\mathrm{t} / \mathrm{q}=1 /\left(\mathrm{k} \mathrm{q}_{\mathrm{e}}{ }^{2}\right)+\mathrm{t} / \mathrm{q}_{\mathrm{e}}$

Since $\mathrm{q}$ reaches $\mathrm{q}_{\mathrm{e}}$ at equilibrium, $\mathrm{q}$ values smaller than $0.9 \mathrm{q}_{\mathrm{e}}$ are used for analysis. Plots of $\ln \left(\mathrm{q}_{\mathrm{e}}-\mathrm{q}\right)$ versus $\mathrm{t}$ and $\mathrm{t} / \mathrm{q}$ versus $\mathrm{t}$ are used to test the first- and second-order models and the fitting results are given in Table 6-9. Both line curve fit and $\mathrm{q}_{\mathrm{e}, \mathrm{cal}}$, second-order model gives more well results than firstorder model. So the kinetics parameter of both adsorption and competitive adsorption can all be described by second-order model. In addition, there is not obvious correlation between adsorption rate constant and the adsorption temperature.
Based on second-order model, eqn. 7 and 8, adsorption rate and half adsorption time of these adsorbates are calculated.

$$
\begin{gathered}
\mathrm{u}=\mathrm{kq}_{\mathrm{e}}{ }^{2} \\
\mathrm{t}_{\mathrm{1} / 2}=1 /\left(\mathrm{kq}_{\mathrm{e}}\right)
\end{gathered}
$$

where, $\mathrm{u}$ : initial adsorption rate, $\left(\mathrm{mg} \mathrm{g}^{-1} \min ^{-1}\right)$; $\mathrm{t}_{1 / 2}$ : halfadsorption time, (min) for PEG 10000 and (h) for ABR.

As showed in Tables 10-12, $\mathrm{u}$ is found to increase with the increase of adsorbates initial concentration and temperature and $t_{1 / 2}$ decrease with the increase of temperature.

Second-order rate constants are used to calculate adsorption activation energy according to eqn. (9). Results listed in Tables 10 and 11 show that the activation energy in adsorption are all lower than $40 \mathrm{~kJ} \mathrm{~mol}^{-1}$, which indicates that adsorption of the reference compounds on expanded graphite are mainly physical adsorption. 


\begin{tabular}{cccccc}
\hline \multicolumn{6}{c}{ TABLE-10 } \\
\multicolumn{6}{c}{ KINETIC PARAMETERS OF XYLENOL ORANGE FOR THE } \\
SECOND-ORDER MODEL IN SINGLE ADSORPTION \\
\hline $\begin{array}{c}\mathrm{C}_{0} \\
\left(\mathrm{mg} \mathrm{L}^{-1}\right)\end{array}$ & $\begin{array}{c}\mathrm{T} \\
\left({ }^{\circ} \mathrm{C}\right)\end{array}$ & $\begin{array}{c}\mathrm{u} \\
\left(\mathrm{mg} \mathrm{g}^{-1} \mathrm{~min}^{-1}\right)\end{array}$ & $\begin{array}{c}\mathrm{t}_{1 / 2} \\
(\mathrm{~min})\end{array}$ & $\begin{array}{c}\mathrm{E}_{\mathrm{a}} \\
\left(\mathrm{kJ} \mathrm{mol}^{-1}\right)\end{array}$ & $\mathrm{r}$ \\
\hline \multirow{2}{*}{100} & 15 & 0.0743 & 572.96 & & \\
& 25 & 0.0976 & 416.67 & 14.281 & -0.994 \\
& 35 & 0.1219 & 321.43 & & \\
\hline \multirow{2}{*}{200} & 15 & 0.0783 & 719.41 & & \\
& 25 & 0.1081 & 445.97 & 17.506 & -0.999 \\
\hline
\end{tabular}

TABLE-11

KINETIC PARAMETERS OF SODIUM ANTHRAQUINONE-1SULFONATE FOR THE SECOND-ORDER MODEL IN SINGLE ADSORPTION

\begin{tabular}{cccccc}
\hline $\begin{array}{c}\mathrm{C}_{0} \\
\left(\mathrm{mg} \mathrm{L}^{-1}\right)\end{array}$ & $\begin{array}{c}\mathrm{T} \\
\left({ }^{\circ} \mathrm{C}\right)\end{array}$ & $\begin{array}{c}\mathrm{u}\left(\mathrm{mg} \mathrm{g}^{1}{ }^{1}\right. \\
\left.\mathrm{min}^{-1}\right)\end{array}$ & $\begin{array}{c}\mathrm{t}_{1 / 2} \\
(\mathrm{~min})\end{array}$ & $\begin{array}{c}\mathrm{E}_{\mathrm{a}} \\
\left(\mathrm{kJ} \mathrm{mol}^{-1}\right)\end{array}$ & $\mathrm{r}$ \\
\hline \multirow{3}{*}{100} & 15 & 2.61 & 8.24 & & \\
& 25 & 3.79 & 6.09 & 16.769 & -1 \\
& 35 & 4.63 & 4.95 & & \\
\hline \multirow{2}{*}{200} & 15 & 1.04 & 19.8 & & -0.9768 \\
& 25 & 5.43 & 4.34 & 27.755 & \\
\hline
\end{tabular}

TABLE-12

KINETIC PARAMETERS OF COMPETITIVE ADSORPTION FOR THE SECOND-ORDER MODEL ${ }^{\mathrm{d}}$

\begin{tabular}{|c|c|c|c|c|c|c|}
\hline \multicolumn{2}{|c|}{$\begin{array}{c}\mathrm{C}_{0} \\
\left(\mathrm{mg} \mathrm{L}^{-1}\right) \\
\end{array}$} & $\begin{array}{c}\mathrm{T} \\
\left({ }^{\circ} \mathrm{C}\right) \\
\end{array}$ & $\begin{array}{c}\mathrm{u}\left(\mathrm{mg} \mathrm{g}^{-1}\right. \\
\left.\mathrm{min}^{-1}\right)\end{array}$ & $\begin{array}{c}\mathrm{t}_{1 / 2} \\
(\mathrm{~min})\end{array}$ & $\begin{array}{l}\mathrm{E}_{\mathrm{a}}(\mathrm{kJ} \\
\left.\mathrm{mol}^{-1}\right)\end{array}$ & $r$ \\
\hline \multirow{6}{*}{ XO } & \multirow{3}{*}{100} & 15 & 0.489 & 30.305 & \multirow{3}{*}{18.815} & \multirow{3}{*}{-1} \\
\hline & & 25 & 0.507 & 26.265 & & \\
\hline & & 35 & 1.363 & 17.476 & & \\
\hline & \multirow{3}{*}{200} & 15 & 0.682 & 51.78 & \multirow{3}{*}{0} & \multirow{3}{*}{-1} \\
\hline & & 25 & 1.047 & 22.46 & & \\
\hline & & 35 & 1.487 & 12.98 & & \\
\hline \multirow{6}{*}{ SAS } & \multirow{3}{*}{100} & 15 & 0.094 & 46.22 & \multirow{3}{*}{0} & \multirow{3}{*}{-1} \\
\hline & & 25 & 0.197 & 18.24 & & \\
\hline & & 35 & 0.362 & 10.34 & & \\
\hline & \multirow{3}{*}{200} & 15 & 0.085 & 32.42 & \multirow{3}{*}{0} & \multirow{3}{*}{-1} \\
\hline & & 25 & 0.193 & 22.73 & & \\
\hline & & 35 & 0.344 & 13.30 & & \\
\hline
\end{tabular}

${ }^{\mathrm{d}}$ Concentrations of competitive component are $100 \mathrm{mg} \mathrm{L}^{-1}$ and $200 \mathrm{mg}$ $\mathrm{L}^{-1}$, respectively

$$
\ln \mathrm{k}=\ln \mathrm{A}-\mathrm{E}_{\mathrm{a}} /(\mathrm{RT})
$$

where, A: Re-exponential factor, $\left(\mathrm{g} \mathrm{mg}^{-1} \mathrm{~min}^{-1}\right)$; $\mathrm{E}_{\mathrm{a}}$ : Activation energy of adsorption, $\left(\mathrm{kJ} \mathrm{mol}^{-1}\right)$.

\section{Conclusion}

This study has provided an insight into the adsorption and competitive adsorption isotherm, thermodynamic parameter, kinetic model and parameter of expanded graphite for xylenol orange and sodium anthraquinone-1-sulfonate. The results are summarized as follows:
Expanded graphite possesses adsorption capacity for both xylenol orange and sodium anthraquinone-1-sulfonate, the adsorption and competitive adsorption isotherm are type I for sodium anthraquinone-1-sulfonate and type II for xylenol orange. In competitive adsorption of dual component system, the existence of another component would decrease the adsorbance of expanded graphite for single adsorbate, which might be caused by the competitive adsorption for the same adsorbing site on expanded graphite. Adsorption and competitive adsorption of sodium anthraquinone-1-sulfonate and xylenol orange on expanded graphite are all spontaneous and the increase of ionic strength, temperature and expansion volume of expanded graphite would cause the increase of adsorption capacity. No matter single adsorption or competitive adsorption, the adsorption kinetic models can all be well described with pseudo second-order kinetic model. Physical adsorption is the main action between expanded graphite and sodium anthraquinone-1-sulfonate or expanded graphite and xylenol orange.

\section{REFERENCES}

1. G.M. Walker and L.R. Weatherley, Chem. Eng. J., 83, 201 (2001).

2. C. Namasivayam and D. Kavitha, Dyes Pigments, 54, 47 (2002).

3. S. Suresh, R.W. Sugumar and T. Maiyalagan, Asian J. Chem.,, 23, 4486 (2011).

4. C. Theivarasu and S. Mylsamy, Asian J. Chem.,, 24, 2187 (2012).

5. A. Adak, M. Bandyopadhyay and A. Pal, Dyes Pigments, 69, 245 (2006).

6. K. Silke, K.U. Anja and J. Martin, Water Res., 36, 4717 (2002).

7. H.C. Chu and K.M. Chen, Proc. Biochem., 37, 595 (2002).

8. H.C. Chu and K.M. Chen, Proc. Biochem., 37, 1129 (2002).

9. A.K. Jain, V.K. Gupta and A.S. Bhatnagar, J. Hazard. Mater. B, 101, 31 (2003).

10. H. Zhao, W. Zhou, N.Z. Cao, W.C. Shen and Y.P. Zheng, Mater. Sci. Eng., 20, 153 (2002).

11. F.Y. Kang, Y.P. Zheng, H. Zhao, H.N. Wang, L.N. Wang, W.C. Shen and M. Inagaki, New Carbon Mater, 18, 161 (2003).

12. M. Toyoda, K. Moriya, J.I. Aizawa, H. Konno and M. Inagaki, Desalination, 128, 205 (2000).

13. M. Inagaki, H. Konno, M. Toyoda, K. Moriya and T. Kihara, Desalination, 128, 213 (2000).

14. M. Inagaki, K. Shibata, S. Setou, M. Toyoda and J.I. Aizawa, Desalination, 128, 219 (2000).

15. M. Toyoda, Y. Nishi, N. Iwashita and M. Inagaki, Desalination, 151, 139 (2003).

16. M. Inagaki, T. Nagata, T. Suwa and M. Toyoda, New Carbon Mater, 21, 97 (2006).

17. X.Y. Pang, L.J. Xu, Y.J. Su, P. Lv and X.H. Liang, J. Mater. Sci. Eng., 2, 49 (2008).

18. X.Y. Pang, E-J. Chem., 7, 1258 (2010).

19. China State Bureau of Quality and Technical Supervision. The Chemical Analysis Method of Graphite GB/T 3521-1995. Beijing: Publishing House of Chinese Standard, pp. 1-10 (1995).

20. M.S. Chiou and H.Y. Li, J. Hazard. Mater, 93, 233 (2002).

21. Z.J. Wu, J. Hyeonwoo and T.L. Kang, Chem. Eng. J., 112, 227 (2005). 